
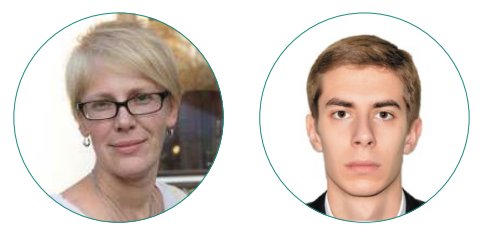

Н. А. Нартова, А. М. Фатехов

\title{
ПЕРЕХОД ВО ВЗРОСЛОСТЬ РОССИЙСКИХ МИЛЛЕНИАЛОВ: НА ПУТИ ОТ ПОЛУЧЕНИЯ ОБРАЗОВАНИЯ К ОБРЕТЕНИЮ ОТВЕТСТВЕННОСТИ И ПОТЕРЕ ОПТИМИЗМА?
}

\section{Правильная ссылка на статью:}

Нартова Н.А., Фатехов А. М. Переход во взрослость российских миллениалов: на пути от получения образования к обретению ответственности и потере оптимизма? // Мониторинг общественного мнения: экономические и социальные перемены. 2021. № 4. С. 319-344. https://doi.org/10.14515/monitoring.2021.4.1832.

\section{For citation:}

Nartova N. A., Fatekhov A. M. (2021) The Transition Into Adulthood of Russian Millennials: On the Way From Getting an Education to Gaining Responsibility and Losing Optimism? Monitoring of Public Opinion: Economic and Social Changes. No. 4. P. 319-344. https://doi.org/10.14515/ monitoring.2021.4.1832. (In Russ.) 
ПЕРЕХОД ВО ВЗРОСЛОСТЬ РОССИЙСКИХ МИЛЛЕНИАЛОВ: НА ПУТИ ОТ ПОЛУЧЕНИЯ ОБРАЗОВАНИЯ К ОБРЕТЕНИЮ ОТВЕТСТВЕННОСТИ И ПОТЕРЕ ОПТИМИЗМА?

НАРТОВА Надежда Андреевна - старший научный сотрудник, Центр молодежных исследований, Национальный исследовательский университет "Высшая школа экономики" в Санкт-Петербурге, Санкт-Петербург, Россия

E-MAIL: nnartova@hse.ru http://orcid.org/0000-0001-9026-3047

ФАТЕХОВ Александр Маратович - стажер-исследователь, Центр молодежных исследований, Национальный исследовательский университет «Высшая школа экономики" в Санкт-Петербурге, Санкт-Петербург, Россия

E-MAIL: amfatekhov@edu.hse.ru https://orcid.org/0000-0001-8945-732X

Аннотация. В современном мире молодость выступает не только и не столько автономным этапом жизни человека, сколько периодом обретения компетенций и навыков, необходимых для взрослой жизни. Взрослость же рассматривается как ценность и цель, достижение которой дает человеку статус полноценного члена общества и "полноценной" личности. Классическая модель перехода во взрослость, сформировавшаяся в середине XX века, все менее релевантна изменившимся условиям современности. Актуальная социологическая дискуссия показывает, что достижение взрослости все так же связано с прохождением социодемографических этапов, однако их последовательность и временная разметка в рамках биографий меняются. Более того, возрастает значение субъективно
THE TRANSITION INTO ADULTHOOD OF RUSSIAN MILLENNIALS: ON THE WAY FROM GETTING AN EDUCATION TO GAINING RESPONSIBILITY AND LOSING OPTIMISM?

Nadezhda A. NARTOVA ${ }^{1}$ - Senior Research Fellow, Centre for Youth Studies E-MAIL:nnartova@hse.ru http://orcid.org/0000-0001-9026-3047

Alexander M. FATEKHOV ${ }^{1}$ - Research Assistant, Centre for Youth Studies E-MAIL:amfatekhov@edu.hse.ru https://orcid.org/0000-0001-8945-732X

${ }^{1}$ HSE University in St. Petersburg, St. Petersburg, Russia

Abstract. Today youthfulness is not only an autonomous stage of life course, but a period of acquiring the competences and skills necessary for adult life. Adulthood is seen as a goal and value, the achievement of which gives a person the status of a full member of society and a "full" personality. The classical model of the transition to adulthood, which was formed in the middle of the 20th century, is becoming less and less relevant in the changed conditions of modernity. Current sociological discussion shows that achieving adulthood is also linked to socio-demographic stages, but their sequence and temporality are changing within biographies. Moreover, subjectively experienced characteristics of growing up, such as autonomy and responsibility, are becoming increasingly important. 
переживаемых характеристик взросления, таких как обретение автономности и ответственности.

Опираясь на доступные данные всероссийских репрезентативных ежемесячных опросов "Курьер" за 20182019 гг. и исследования "Российское “Поколение Z”: Установки и ценности", авторы анализируют переход во взрослость российского поколения миллениалов и демонстрируют, что для современной российской молодежи транзиция во взрослость начинается с получения образования и выхода на рынок труда, сопровождается повышением ответственности, но приводит к снижению удовлетворенности жизнью, ухудшению настроения и потере оптимизма.

Ключевые слова: молодежь, взросление, взрослость, поколение, миллениалы
Based on the available data from the all-Russian representative monthly surveys "Courier" and the research "Russian Generation Z: Settings and Values", the article analyses the transition to adulthood of the Russian millennials and demonstrates that for today's Russian youth, the transition to adulthood begins with education and entry into the labour market, is accompanied by an increase of responsibility, but also leads to a decrease in life satisfaction, a worsening of moods and loss of optimism.

Keywords: youth, transition to adulthood, adulthood, generation, millennials

\section{Введение}

Концепция жизненного курса предполагает, что человеческая жизнь организована как цепь последовательных этапов, каждый из которых подвергается социокультурной регуляции, наделяется определенными ролями и статусами, связывается со специфическими внутренними логиками проживания. Безусловно, возможности социальной деконструкции возраста ограничены, и жизненные этапы так или иначе связаны с био-физиологическими основаниями жизни человека [Twigg, 2004], однако ключевую роль в наделении значениями особенно серединных этапов, таких как молодость и взрослость, играют все-таки социальные интерпретации, которые историчны, контекстуальны и изменчивы.

В современной западной культуре молодость рассматривается как переходный этап от детства к взрослости. Ее наделяют характеристиками неустойчивости, частичной зависимости, динамики, уязвимости [Carpenter, Mojab, 2017; Smith et al., 2011]. Ю. Зубок и В. Чупров пишут, что “особенности социального положения и сознания молодых людей - неустойчивость, переходность, лабильность" [Зубок, Чупров, 2020: 14]. Молодость - это не столько автономный период жизни, сколько нахождение "между". Е. Павленко подчеркивает, что “молодость - это такое символическое пространство, которое уже не управляется категоризацией „ребенок“, но и не может быть проинтерпретировано через категорию „взрослости“, что оставляет подростков и молодежь в позиции амбивалентности» [Павленко, 2016: 265]. 
Взрослость же, в свою очередь, связывается с метафорой «полноценной личности" (full personhood) [Blatterer, 2007: 776]. Взрослость дает доступ ко множеству ресурсов, пространств и статусов, в том числе тех, которые не доступны для других возрастных категорий. Взрослость дарует автономию и позицию полноценного гражданина [Kravchenko, 2015: 304]. Г. Блаттерер указывает, что взрослость в современном обществе обозначает статус человека как полноправного партнера по взаимодействию [Blatterer, 2007: 780].

Получение статуса взрослого не происходит одномоментно, а связано с относительно длительным периодом перехода во взрослость. Е. Митрофанова определяет взросление как "комплексный процесс трансформации ребенка и обретения им опыта и статусов, позволяющих занять самостоятельную позицию в обществе» [Митрофанова, 2019: 55]. Дж. Арнетт называет молодость периодом нарождающейся взрослости [Arnett, 2014]. Иначе говоря, молодость - это обретение навыков и компетенций для взрослой жизни. Задача молодых - пройти через этот этап жизни и стать победителями, то есть взрослыми. Цель молодости - взрослость.

"Классическая модель" взрослости, обеспечиваемая довольно быстрым последовательным прохождением юношами и девушками в возрасте 20-25 лет ряда этапов, таких как отделение от родителей, выход на рынок труда, брак и рождение детей, сформировалась во второй половине XX века [Blatterer, 2007]. Несмотря на то, что структурные условия с 1970-х годов существенным образом изменились, неспособность или невозможность такого перехода молодежью проблематизируется и порождает моральные паники вокруг молодежи, которой приписывается инфантильность [Ардельянова, Саидов, 2018; Мамычева, 2010]. Индивидуализация, прекаризация, изменение структуры рынков труда и жилья, развитие социальных медиа и потребления во многом размывают границы между жизненными этапами, поскольку в этих одинаково нестабильных и рисковых условиях протекают жизни как хронологически молодых, так и хронологически взрослых [Hayward, 2013]. Более того, современная рыночная культура, ориентированная на динамизм, гибкость и мобильность, конституирует молодежный образ жизни как универсальный [Blatterer, 2010]. Однако это не приводит к пересмотру концепций "молодости" и "взрослости" или отказу от них. Взрослость в социологии сохраняет свое функционирование как предзаданная и стабильная категория, оставаясь в культуре целью и благом, к которой нужно стремиться [Blatterer, 2007].

В фокусе данной статьи анализ перехода во взрослость российского поколения миллениалов, а именно молодежи, рожденной в период с 1980 по 2000 г. [Радаев, 2019]. Взросление этого поколения интересно по нескольким причинам. Во-первых, их молодость происходит в относительно стабильных условиях новой России, что структурно существенным образом отличает контекст их взросления от поколения их родителей и прародителей. Во-вторых, данное поколение в целом заметно отличается от предшествующих по своему образу жизни и ценностям [Омельченко, 2020; Радаев, 2019]. В-третьих, именно на долю этого поколения пришлась основная современная дискуссия о Питерах Пенах, кидалтах и других персонажах, не желающих взрослеть.

На основании вторичного анализа количественных данных мы выясняем, совершает ли современная российская молодежь конвенциональный переход 
во взрослость по сложившейся модели взросления, связанной с ключевыми событиями и с персональными характеристиками, и как она себя чувствует в этой взрослости.

\section{Переход во взрослость: теоретические основания исследования}

Современная дискуссия о взрослении выстраивается вокруг двух ключевых перспектив: анализа социо-демографических событий перехода во взрослость и персонифицированного понимания взросления. Первая перспектива основывается на классической модели взросления и предполагает, что достижение взрослости связано с прохождением ряда “значимых событий, меняющих социальный статус человека и устройство его жизни" [Митрофанова, 2019: 56], выступающих маркерами взрослости. Такими событиями традиционно считаются: получение образования, выход на рынок труда, отделение от родителей, создание собственной семьи и рождение детей. Данные транзиции могут рассматриваться как по отдельности [O’Reilly et al., 2018; Irwin, Nilsen, 2018; Patrick, Schulenberg, O’Malley, 2016; Долгова, Митрофанова, 2015], так и в той или иной совокупности [Krahn et al., 2018; Beattie, 2017; Berzin, Marco, 2010]. Особый интерес в рамках данной перспективы представляют исследования, в которых процессуальность взросления анализируется через возраст наступления стартовых событий, их последовательность и продолжительность периода от первого до последнего. Так, Х. Кран и коллеги, анализируя возраст наступления транзитных событий для когорты 1967 г.в Канаде, вводят понятия "первая ступень взросления", в которую включают работу на полную занятость, окончание формального образования и уход из родительского дома, и "вторая ступени взросления", куда относятся партнерство, рождение детей и покупка собственного дома [Krahn et al., 2018: 910]. Кран и коллеги указывают на то, что между первой и второй ступенями появляется значительный временной разрыв, и если события первой ступени наступают довольно быстро, то события второй откладываются на более поздний возраст [ibid.: 914]. И хотя, как подчеркивают исследователи, значительная часть когорты совершила переход во взрослость в целом в рамках традиционных возрастных норм, они добавочно выделяют еще четыре профиля транзиции [ibid.: 915]:

- «быстрые взрослые» (проходят все этапы быстрее сверстников),

- "неуверенные взрослые" (начали работать сразу по окончании школы, но другие переходы отложили во времени),

- «взрослые студенты» (совершили большинство переходов вовремя, кроме получения образования),

- "задержавшиеся взрослые" (которые много времени и сил потратили на учебу, соответственно, завершили этот этап позже, чем в среднем, и другие события у них наступили также позднее).

В целом Х. Кран и коллеги говорят, что уже для когорты, чья молодость пришлась на 1990-е годы, взросление становится более индивидуализированным, пролонгированным и нелинейным, чем это представлено в классических моделях середины XX века [ibid.: 907].

Для понимания российского контекста важна работа Е. Митрофановой [Митрофанова, 2019], в которой автор анализирует специфику перехода во взрос- 
лость шести советских и постсоветских поколений. В отличие от Х. Крана и коллег, Е. Митрофанова не определяет события перехода как ступени, а группирует их как "социоэкономические (завершение получения образования, первое трудоустройство, первое покидание родительского дома) и демографические (первое партнерство, первый брак, рождение первого ребенка)" [там же: 59], что позволяет ей увидеть изменения в моделях взросления в разных исторических и институциональных условиях. Исследовательница выделяет три модели взросления россиян:

- “советскую" (поколения 1940-1949, 1950-1959, 1960-1969 г. р.), которая близка к "традиционной модели" и характеризуется тем, что "события наступают в молодых возрастах; интенсивность - малые интервалы между событиями; последовательность наступления событий простая и предсказуемая" [там же: 70];

- «переходную" (поколения 1930-1939 и 1970-1979 г. р.), которая выстраивалась в периоды перемен и нестабильности, когда «индивиды откладывают наступление одних событий и приоритизируют наступление других" [там же: 68];

- "постсоветскую" (поколения 1980-1986 г.р.), которая приближается к "современной", где "тайминг - откладывание событий на более поздние возрасты; интенсивность - рост интервалов между событиями; последовательность наступления событий сложная и непредсказуемая" [там же: 70].

Е. Митрофанова подчеркивает, что в целом «границы взросления меняются очень медленно" и "в среднем для россиян характерно наступление стартовых событий в интервале от 17-18 и до 25-27 лет" [там же: 62], однако последовательность, интенсивность и их тайминг меняются. Про самое молодое в своем исследовании поколение автор пишет: “Стандартные социоэкономические события у поколения 80-х годов рождения наступают примерно в тех же возрастах и с той же интенсивностью, что и у двух предыдущих поколений. Возраст первого трудоустройства немного откладывается, но это объясняется более длительным получением профессионального образования. Среди первых демографических событий предпочтение чаще отдается партнерствам, тогда как события, требующие принятия более долгосрочной ответственности (браки и деторождения), откладываются на более поздние возрасты» [там же: 67]. При этом Е. Митрофанова подчеркивает, что «молодежь не уклоняется от взросления, но, становясь активным участником этого процесса, начинает менять его структуру и календарь" [там же: 67].

Второй подход к изучению взросления вырос из исследований “нарождающейся взрослости" Дж. Арнетта [Arnett, 2014] и базируется на реконструировании конвенционально разделяемых, но персонально, лично переживаемых характеристиках взросления. Арнетт показывает, что для современной молодежи взрослость связана с тремя ключевыми аспектами: принятием ответственности за себя, возможностью независимых решений и обретением финансовой независимости [ibid.: 313]. Процесс становления взрослым - это, по сути, процесс обретения самостоятельности, научения "жить одному" [ibid.: 332]. Исследование И. Питти показывает, что для молодых итальянцев взрослость в первую очередь определяется через "ответственность" и "независимость" [Pitti, 2017: 1230]. Это роднит их с родителями, которые так же описывают взрослость через эти две 
ключевые категории. Однако если для родительского поколения, людей вполне уже реализующих взрослость, ответственность - это ответственность за других, то для молодых людей важнее, что их признают готовыми взять на себя ответственность [ibid.: 1230]. Независимость же для молодежи связана с образом жизни и потреблением, а также с экономической независимостью, в то время как для взрослых - с более абстрактными выборами, касающимися приватной и публичной жизни [ibid.: 1231]. Питти указывает, что девушки и взрослые женщины "особенно подчеркивали независимость как фундаментальный элемент их взрослого статуса" [ibid.: 1231]. Российское исследование конструирования возраста девушками и женщинами также показывает, что взрослость во многом связывается ими с возможностью и способностью автономных и независимых действий [Omelchenko, Nartova, Krupets, 2018]. Е. Павленко и А. Якубовская в своей работе, посвященной пониманию взрослости среди учащихся СТО и старшеклассников, приходят к выводу, что "среди основных интерпретаций: взрослость как определяемая средой иерархическая категория, взрослость как умение контролировать себя, как умение брать на себя ответственность и принимать самостоятельные решения, как финансовая независимость" [Павленко, Якубовская, 2020: 388]. К. Ч. Вогт, анализируя биографические интервью с молодыми норвежцами, показывает, что их способ артикуляции своего взросления связан в первую очередь со словарем "индивидуального выбора" и "персональной ответственности", в отличие от старшего поколения, которое свое взросление и выбор трудовой траектории рассматривало как детерминированные семьей и условиями локального сообщества [Vogt, 2018]. При этом исследователи подчеркивают, что персонифицированное понимание взрослости не отменяет прохождения молодежью традиционных этапов взросления, скорее обогащает взросление, делает его более рефлексивным, вариабельным, гибким [Walsh, Keary, Gleeson, 2019].

Говоря об исследованиях взросления, важно уточнить, что в вариабельности переходов во взрослость существенную роль играют структурные условия и наличествующие ресурсы. Национальные институциональные контексты, включая реализуемые государствами молодежные политики, задают "режимы перехода" [Walther, 2006], которые во многом определяют траектории для молодежи в ее взрослении [Чернова, Шпаковская, 2020]. Более того, социоэкономическое, культурное, расовое неравенство между разными группами молодежи, будет одним открывать новые возможности, другим - закрывать перспективы. Например, выходцы из высокодоходных семей пролонгируют время на образование, поскольку родители могут платить за обучение и поддерживать детей в этот период, а молодежь из низкодоходных семей, наоборот, стимулируется к быстрому получению образования и раннему выходу на рынок труда [Kravchenko, 2015: 307]. Множественные изменения, происходящие в современном мире, осложняют для молодежи не только транзицию, но и конечную точку назначения - ту взрослость, которую они смогут реализовывать, - усиливая риски прекаризации, социальной незащищенности, бедности [ibid.: 314]. Возможно, поэтому молодежь иногда рассматривает взрослость "скорее, как что-то неизбежное, чем желаемое и предвкушаемое" [Павленко, Якубовская, 
2020: 388]. Хотя, как отмечает Л. Уолш с коллегами в своем исследовании, "для всех поколений нестабильность - стабильный нарратив" [Walsh, Keary, Gleeson, 2019: 481]. Вероятно, в силу этого взросление, связанное с обретением самостоятельности, принятием ответственности через прохождение ряда жизненных этапов, остается задачей для любого поколения, требующей научиться совладать с окружающим миром.

\section{Методология и эмпирическая база исследования}

В фокусе данной статьи ${ }^{1}$ переход к взрослости современной российской молодежи. Переход к взрослости сопровождается как проживанием определенного ряда социо-демографических событий, так и обретением ряда субъективно переживаемых характеристик. Опираясь на доступные данные всероссийских репрезентативных ежемесячных опросов "Курьер" ${ }^{2}$, проводимых автономной некоммерческой организацией "Аналитический Центр Юрия Левады" (АНО "Левада-Центр" $\left.{ }^{3}\right)$, и данные исследования “Российское „Поколение Z“: Установки и ценности" ${ }^{4}$, проведенного Фондом им. Фридриха Эберта, в качестве объективизированных маркеров взросления нами рассматриваются "классические" социо-демографические события: получение образования, выход на рынок труда, отделение от родителей, начало совместной жизни с партнером, брак и рождение детей. Данные маркеры позволяют описать общую траекторию взросления российской молодежи. В качестве субъективизированных маркеров взросления нами рассматриваются индивидуально оцениваемые чувства ответственности за других - за происходящее в семье, на работе, в доме и т. д. Достижение статуса взрослого в культуре наделено высокой ценностью и связано с обретением автономии, независимости и полноценного членства в обществе, поэтому в качестве "контрольных" маркеров, позволяющих оценить субъективно переживаемое становление агентности, мы рассматриваем возможности в планировании будущего, удовлетворенность наличествующей жизнью, ожидание перемен в жизни, текущее настроение.

Объектом данного исследования выступает поколение "миллениалов" - современная российская молодежь, рожденная в период с 1980 по 2000 г., чье взросление пришлось на период политической и экономической стабилизации. Однако данное поколение не однородно, различные возрастные группы находятся на разных этапах взросления, так, 20-летние только начинают свой переход, а 40-летние его уже практически завершили. Поэтому в поколении миллениалов мы выделили три возрастные когорты, которые в 2020 г. находятся в возрасте

\footnotetext{
1 Статья подготовлена в рамках проекта “Взросление российской молодежи в 21 веке: поколенческий анализ", реализуемого Центром молодежных исследований НИУ ВШЭ СПб в 2020-2022 гг. при поддержке Национального исследовательского университета "Высшая школа экономики".

2 Данные доступны в Едином архиве экономических и социологических данных URL: http://sophist.hse.ru/db/oprosy. shtml?ts=32\&en=0 (дата обращения: 16.08.2021).

3 Российское юридическое лицо, выполняющее функции иностранного агента.

4 Возможность использования данных исследования "Российское „Поколение Z“: Установки и ценности” для научных целей любезно предоставлена Фондом им. Фридриха Эберта Центру молодежных исследований. Данные опроса находятся на портале Фонда Фридриха Эберта. URL: https://www.fes-russia.org/proekty/pokolenie-z/ (дата обращения: 16.08.2021).
} 
двадцати, тридцати и сорока лет, включая пограничные хронологические возраста, то есть люди 1997-2002, 1987-1992 и 1978-1982 годов рождения соответственно. Для удобства эти группы мы условно называем: “младшая" - 18-23 г., "средняя" - 28-33 г. и "старшая" - 38-42 г. В качестве контрольной группы, которая позволяет увидеть специфику взросления нынешней молодежи, выделена когорта "Взрослых", а именно предыдущее “миллениалам" «поколение X" [Радаев, 2019] - люди в возрасте 43-60 лет на момент исследования.

Данные из всероссийских репрезентативных ежемесячных опросов "Курьер” за 2018-2019 гг. отбирались в соответствии с возрастными когортами, заданными в исследовании так, чтобы на момент проведения исследования, то есть в 2020 г., возраст респондентов соответствовал определенным нами возрастным интервалам. Данные отобранных волн "Курьера", использованные для анализа субъективизированных маркеров взросления, сливались в общий массив с группировкой по переменным, повторяющимся в этих волнах с соблюдением возрастных интервалов.

В рамках исследования "Российское „Поколение Z“: Установки и ценности” за май и июнь 2019 г. были опрошены 1500 респондентов в возрасте от 14 до 29 лет. Из этого массива были отобраны респонденты старше 18 лет, итоговая выборка составила 1041 человека. Данные этого исследования использовались для анализа объективизированных маркеров взросления.

При подготовке эмпирических данных к анализу были посчитаны меры центральной тенденции и вариации, рассчитаны описательные статистики, таблицы сопряженности, проведены Хи-квадрат и Z-тесты для проверки гипотез о различиях значений анализируемых показателей между возрастными категориями.

Наше исследование не претендует на полноту описания всех нюансов взросления российской молодежи. Более того, анализ существенно ограничен наличествующими данными, в том числе разницей в доступных для описания возрастных группах в "Курьере" и исследовании "Российское „Поколение Z“: Установки и ценности". Последнее включает молодежь только до 29 лет. Соответственно, мы не можем отследить наступление социо-демографических событий в более поздних возрастах. Наша цель - скорее наметить пунктиром общие тенденции во взрослении российской молодежи сегодня.

\section{Взросление как реализация социо-демографических событий}

Одним из ключевых маркеров взросления является получение образования. У абсолютного большинства опрошенных (98,3\%) молодых россиян в возрасте от 18 до 29 лет в жизни произошло такое событие, как выпуск из одного или нескольких учебных заведений - школы, колледжа или университета. К 18 годам у $50 \%$ опрошенных наступило завершение одного из учебных заведений, наиболее вероятно - школы и/или колледжа, а к 22 годам у $90 \%$ опрошенных наступило завершение образования, вероятнее всего - завершение учебы в высшем учебном заведении (см. рис. 1). Респондентам также задавался вопрос о наступлении в их жизни такого события, как отчисление из учебного заведения. У абсолютного большинства опрошенных (96,9\%) это событие не происходило вовсе. 
Рис. 1. Накопленный процент по произошедшему в жизни молодежи событию: окончили школу/колледж/университет

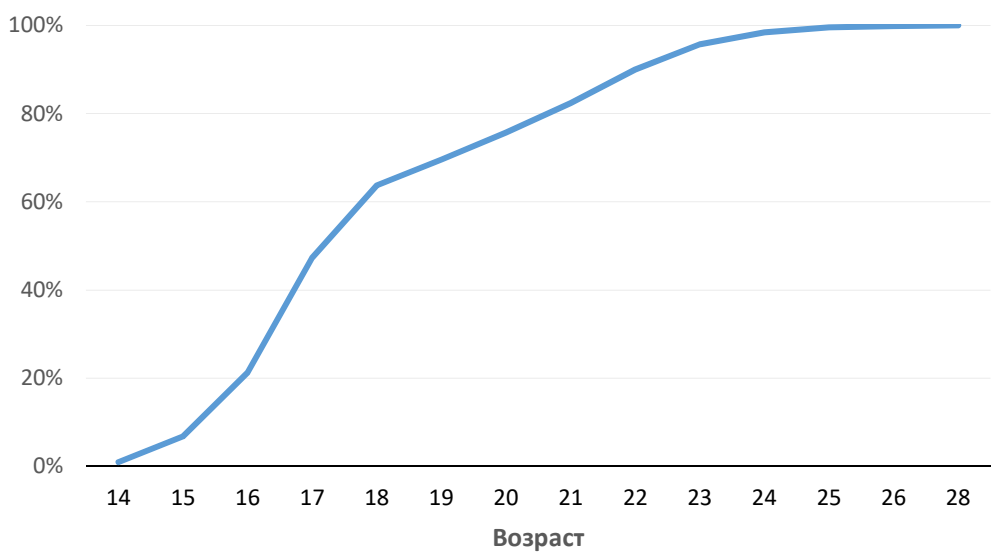

Наиболее распространенный достигнутый уровень образования россиян в целом - среднее профессиональное образование (см. табл. 1). Такое образование есть у 42,5\% взрослого (старше 18 лет) населения России. Высшее образование имеют 27,9 \% всего населения, а 17,8 \% завершили получение образования после средней школы.

Таблица 1. Ваше образование?

\begin{tabular}{|l|c|c|c|c|c|}
\hline & $\begin{array}{c}\text { Младшая } \\
\mathbf{( 1 8 - 2 3 )}\end{array}$ & $\begin{array}{c}\text { Средняя } \\
\mathbf{( 2 8 - 3 3 )}\end{array}$ & $\begin{array}{c}\text { Старшая } \\
\mathbf{( 3 8 - 4 2 )}\end{array}$ & $\begin{array}{c}\text { Контрольная } \\
\mathbf{( 4 3 - 6 0 )}\end{array}$ & $\begin{array}{c}\text { Все на- } \\
\text { селение }\end{array}$ \\
\hline $\begin{array}{l}\text { Начальное или ниже, неполная } \\
\text { средняя школа } \\
\text { (7-8, сейчас 9 классов) }\end{array}$ & 5,4 & 2 & 2,8 & 2 & 4,3 \\
\hline $\begin{array}{l}\text { Средняя школа } \\
\text { (10, сейчас 11 классов) }\end{array}$ & 40,2 & 13,3 & 13,5 & 17,1 & 17,8 \\
\hline $\begin{array}{l}\text { Начальное профессиональное } \\
\text { образование }\end{array}$ & 5,1 & 4 & 4,8 & 5,3 & 4,9 \\
\hline $\begin{array}{l}\text { Среднее профессиональное } \\
\text { образование }\end{array}$ & 33,3 & 38,3 & 42,8 & 47,2 & 42,5 \\
\hline $\begin{array}{l}\text { Неполное высшее } \\
\text { не менее трех курсов вуза) }\end{array}$ & 8,7 & 3 & 2,3 & 1,9 & 2,6 \\
\hline Высшее & 7,4 & 39,3 & 33,8 & 26,5 & 27,9 \\
\hline Сумма & 100 & 100 & 100 & 100 & 100 \\
\hline объем выборки, чел. & $\mathbf{4 4 8}$ & $\mathbf{6 9 9}$ & $\mathbf{8 2 8}$ & $\mathbf{2 0 2 5}$ & $\mathbf{6 4 3 8}$ \\
\hline
\end{tabular}

Источник: Курьер 2019-02/05/09/12. 
Характерно, что наибольшая доля опрошенных по возрастным группам, чей уровень образования ограничивается средней школой, обнаруживается в младшей возрастной когорте. На момент опроса 40,2\% респондентов младшей группы имели в качестве максимального уровня полученного образования среднюю школу. Очевидно, что довольно большая доля из этих людей еще продолжает образовательный процесс. Кроме этого, существует также значимое различие в долях респондентов, получивших среднее профессиональное образование, между младшей и контрольной возрастной когортами. Меньшая доля представителей младшей возрастной когорты получила среднее профессиональное образование.

Среди выделенных в данном исследовании возрастных когорт средняя группа училась в среднем дольше остальных (см. табл. 2). Представители этой возрастной группы учились во всех образовательных учреждениях в совокупности в среднем 13,7 лет. ANOVA-тест, позволяющий установить, значимо ли различаются средние значения в подгруппах, показал, что между выделенными когортами среднее количество лет, затрачиваемых на образование, различается статистически значимо. Проведенный после этого теста post-hoc анализ показал, что младшая возрастная когорта молодежи училась на момент проведения исследования статистически значимо меньше каждой из остальных когорт - в среднем они потратили 12,3 лет на учебу. Это закономерно, учитывая, что часть из них продолжает обучение. При этом средняя возрастная когорта статистически значимо дольше училась во всех учебных заведениях, чем все остальные когорты, кроме старшей - с ней разница не значима. Контрольная группа "взрослых" училась в среднем статистически значимо меньшее количество лет, чем средняя когорта молодежи, но с остальными группами разница не значима.

Таблица 2. Сколько лет в целом Вы учились во всех учебных заведениях?

\begin{tabular}{|l|c|c|c|c|c|}
\hline & $\begin{array}{c}\text { Младшая } \\
\mathbf{1 8 - 2 3}\end{array}$ & $\begin{array}{c}\text { Средняя } \\
\mathbf{2 8 - 3 3}\end{array}$ & $\begin{array}{c}\text { Старшая } \\
\mathbf{3 8 - 4 2}\end{array}$ & $\begin{array}{c}\text { Контрольная } \\
\mathbf{4 3 - 6 0}\end{array}$ & $\begin{array}{c}\text { Все } \\
\text { население }\end{array}$ \\
\hline $\begin{array}{l}\text { Среднее кол-во лет, } \\
\text { затраченных } \\
\text { на образование }\end{array}$ & 12,3 & 13,7 & 13,6 & 13,0 & 13,2 \\
\hline Объем выборки, человек & 93 & 190 & 196 & 512 & 1626 \\
\hline
\end{tabular}

Источник: Курьер 2019-01.

Несмотря на то, что преждевременно делать выводы о достигаемом уровне образования младшей возрастной когортой, поскольку многие ее представители до сих продолжают образовательный процесс, можно заметить, что чем младше рассматриваемое поколение - тем меньшая доля его представителей имеет среднее образование и бо́льшая доля получает высшее образование. Кроме того, $62 \%$ опрошенной в исследовании “Российское „Поколение Z“: установки и ценности" молодежи в возрасте от 18 до 29 лет заявляют, что максимальный уровнем образования, который они хотели бы получить,- высшее (бакалавриат, специалитет или магистратура). 
Таким образом, можно сказать, что один из ключевых маркеров взросления получение образования - достигается российской молодежью. При этом она тратит больше времени на образование, чем старшие поколения, и достигаемый ею уровень формального образования выше. Среди 30- и 40-летних статистически значимо бо́льшая группа респондентов имеет высшее образование по сравнению с представителями контрольной группы взрослых поколения X.

После завершения основного образования молодежь выходит на рынок труда. У $90 \%$ из числа тех, у кого произошел выход на рынок труда, это событие наступило к 22 годам (см. рис. 2). При этом $27 \%$ опрошенных в возрасте от 18 до 29 лет отмечают, что такое событие, как начало первой работы на полную ставку, в их жизни еще не происходило. Из них 71\% составляют люди в возрасте до 21 года. Среди молодежи старше 21 года не начинали работать на постоянной работе всего 8,6\% респондентов.

\section{Рис. 2. Накопленный процент по произошедшему в жизни молодежи событию: начали работать на первой работе на полную ставку}

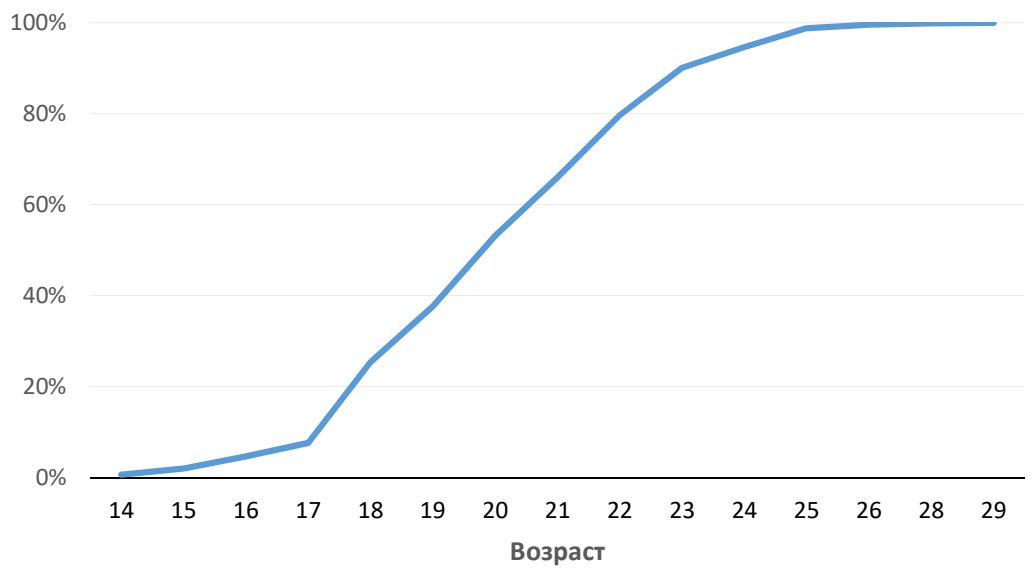

Младшая возрастная когорта молодежи в большинстве своем сконцентрирована на образовательном процессе (см. табл. 3) - 53\% опрошенных 18-23 лет отмечают статус учащегося или студента в качестве своего рода занятий. Среди молодежи средней и старшей возрастных когорт большинство опрошенных заняты в должностях, соответствующих специалисту (без руководящих функций) или рабочего - таков род занятий $25 \%$ - $29 \%$ представителей данных групп молодежи, а в совокупности специалисты и рабочие составляют более половины от всех опрошенных в данных возрастных группах.

Как уже отмечалось, уровень образования в более молодых возрастных когортах (не считая тех, кто в настоящий момент получает образование) выше, чем в более старших. Это различие обнаруживается и в характере занятости. Так, в старшей молодежной когорте доля специалистов без специального образования выше, чем среди средней, а в средней выше доля специалистов с образованием, 
чем в старшей и контрольной. Кроме того, характерно, что в средней возрастной когорте молодежи обнаруживается более высокая, чем в остальных когортах, доля тех, чей основной род занятий - уход за ребенком (13,2\%).

Таблица З. Каков род Ваших занятий? Если работаете в разных местахто по основному месту работы, \%

\begin{tabular}{|c|c|c|c|c|c|}
\hline & $\begin{array}{l}\text { Младшая } \\
(18-23)\end{array}$ & $\begin{array}{l}\text { Средняя } \\
(28-33)\end{array}$ & $\begin{array}{l}\text { Старшая } \\
(38-42)\end{array}$ & $\begin{array}{c}\text { Контрольная } \\
(43-60)\end{array}$ & $\begin{array}{c}\text { Все } \\
\text { население }\end{array}$ \\
\hline $\begin{array}{l}\text { Независимый предпринима- } \\
\text { тель, самозанятый }\end{array}$ & 2,5 & 6,6 & 7,6 & 5,4 & 4,7 \\
\hline $\begin{array}{l}\text { Руководитель, управленче- } \\
\text { ский работник }\end{array}$ & 2,1 & 6 & 6,3 & 4,1 & 4 \\
\hline $\begin{array}{l}\text { Специалист без руководящих } \\
\text { функций (со спец. образ.) }\end{array}$ & 10,4 & 29,9 & 25,4 & 18,9 & 19,1 \\
\hline $\begin{array}{l}\text { Служащий без специального } \\
\text { образования }\end{array}$ & 8,1 & 10 & 14,7 & 12,1 & 10,1 \\
\hline $\begin{array}{l}\text { Рабочий (в том числе мастер, } \\
\text { бригадир), в т. ч. в сельском } \\
\text { хозяйстве }\end{array}$ & 13,5 & 26,4 & 29,8 & 27,2 & 21,1 \\
\hline Учащийся, студент & 53 & 0,5 & 0 & 0 & 4,1 \\
\hline $\begin{array}{l}\text { Пенсионер (неработающий) } \\
\text { по старости/выслуге лет }\end{array}$ & 0 & 0,1 & 0,1 & 17,9 & 22,8 \\
\hline $\begin{array}{l}\text { Пенсионер (неработающий) } \\
\text { по инвалидности }\end{array}$ & 0 & 0,9 & 2,3 & 4,7 & 3,6 \\
\hline $\begin{array}{l}\text { Веду домашнее хозяйство, } \\
\text { ухаживаю за ребенком }\end{array}$ & 3,7 & 13,2 & 7 & 3,7 & 5,5 \\
\hline Не работаю и ищу работу & 4,9 & 5,3 & 5,8 & 4,1 & 3,8 \\
\hline Не работаю и не ищу работу & 1,8 & 1,1 & 1,2 & 1,9 & 1,3 \\
\hline Сумма & 100 & 100 & 100 & 100 & 100 \\
\hline Объем выборки, чел. & 653 & 1006 & 1213 & 3100 & 10339 \\
\hline
\end{tabular}

Источник: Курьер 2019.

Следующим этапом взросления молодежи является переезд от родителей. У $90 \%$ молодежи из числа тех, у кого он наступил, данная транзиция происходит на год позже начала первой работы на полную ставку, то есть в 24 года. Однако можно отметить (см. рис. 3) некий скачок доли тех, кто уехал из родительского дома в возрасте 17 лет. Вероятнее всего, он связан с поступлением в учебное заведение и поселением в общежитии, поскольку в данном возрасте эти события могут совпасть друг с другом. Стоит отметить, что переезд от родителей не происходил в жизни 44,5\% российской молодежи в возрасте от 18 до 29 лет. 
Рис. 3. Накопленный процент по произошедшему в жизни молодежи событию: съехали от родителей

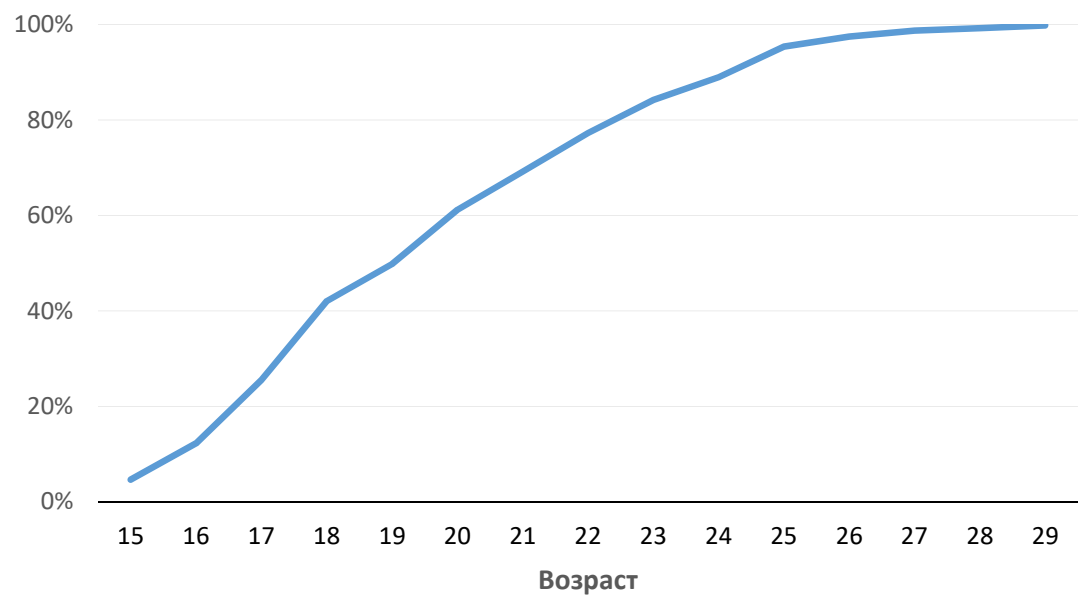

Примерно в этот же период жизни молодежь начинает совместно проживать с партнером/партнершей. У $90 \%$ из тех, у кого в жизни наступило такое событие (доля таких людей составляет 47,4\% от всей выборки старше 18 лет), это произошло к 24 годам (см. рис. 4).

\section{Рис. 4. Накопленный процент по произошедшему в жизни молодежи событию:} начали жить с партнером/партнершей

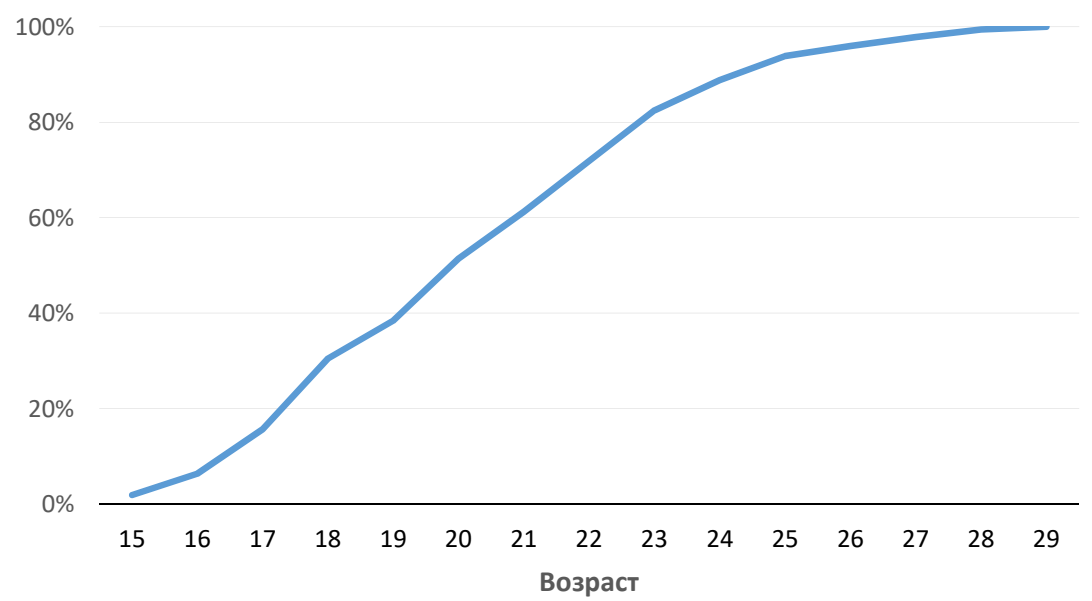


Зачастую начало совместной жизни с партнером/партнершей сопровождается браком: у 90 \% из тех, кто женился или вышел замуж, это событие также наступило к 24 годам (см. рис. 5). Но доля тех, кто до 29 лет так и не вступил в брак, выше, чем тех, кто не начал партнерства. В брак не вступили 68,2\% опрошенных в возрасте от 18 до 29 лет, в то время как без партнера/партнерши живут только 52,6\%.

Рис. 5. Накопленный процент по произошедшему в жизни молодежи событию: женились/вышли замуж

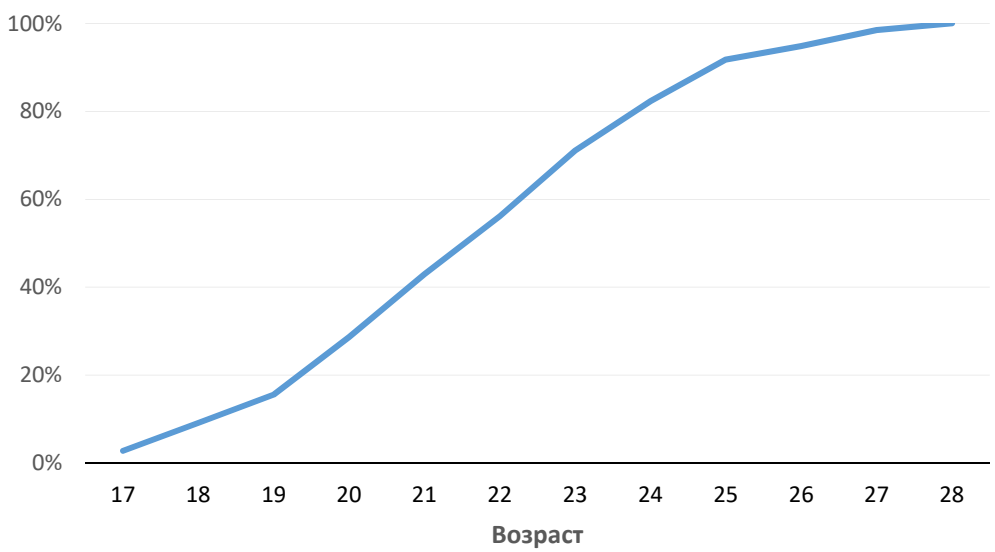

Что касается рождения ребенка, то до 29 лет первый ребенок появился только у $28 \%$ опрошенной молодежи. При этом у $90 \%$ из тех, у кого в жизни это событие произошло, оно наступило к 25 годам (см. рис. 6).

Рисунок 6. Накопленный процент по произошедшему в жизни молодежи событию: родился первый ребенок

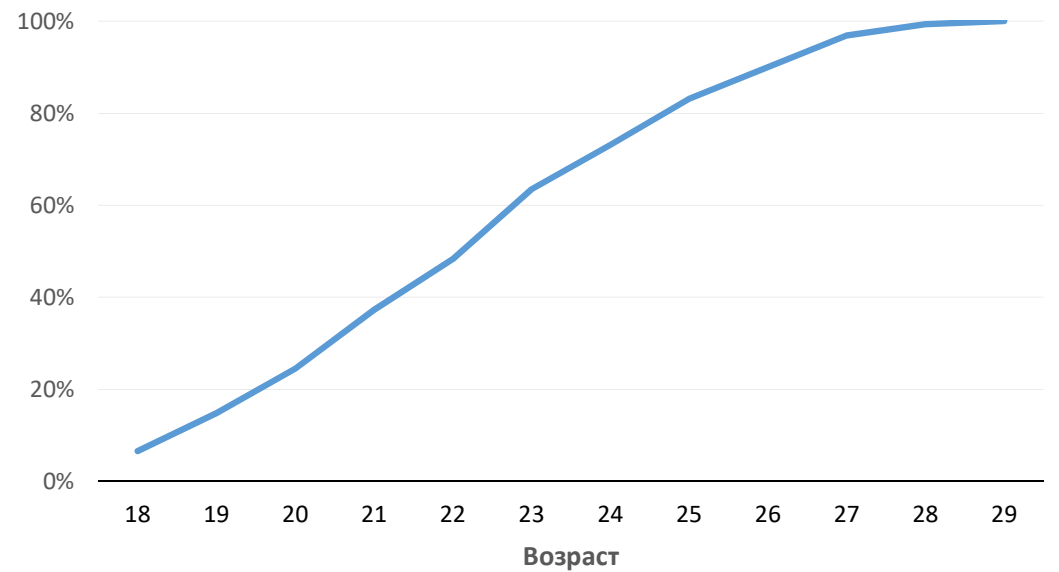


О тех, у кого не наступило то или иное социо-демографическое событие, важно сказать следующее. Среди не вышедшей на рынок труда молодежи больше женщин, чем мужчин (59,4\% и 40,6\% соответственно). Медианный возраст не начавших работать на полную ставку - 19 лет. Доля молодых старше 21 года среди тех, кто пока не начал работать, всего $20 \%$. У большинства опрошенных из данной категории среднее образование. Кроме этого, в данной группе доля тех, у кого не наступали в жизни следующие хронологически ожидаемые события (переезд, брак, рождение детей), выше, чем в целом по выборке. На основании этих данных можно предположить, что для молодежи, которая не вышла на рынок труда и находится в процессе получения профессионального образования, достижение других маркеров взросления пока остается недоступным.

Среди тех, кто не переехал от родителей, практически равные доли мужчин и женщин (50,8\% и 49,2\% соответственно). Медианный возраст живущих в родительской семье составляет 22 года. Более половины молодежи в данной группе имеют уровень образования выше школьного (19\% - специалисты или бакалавры, 3,3\%-магистры или выше, 29,9\% - выпускники колледжей или техникумов, $6 \%$ - не окончили университет). Начали работать на полную ставку 58,5\% из них. 47,2\% опрошенных из этой группы молодежи заявляют, что могут без труда покупать товары повседневного спроса, тогда как покупка товаров длительного потребления для них затруднительна; 32,2\% могут покупать более дорогие вещи, но не такие, как квартира или машина. Сделать на этом материале убедительные предположения, почему молодежь не отделяется от родителей, сложно. Среди причин может быть финансовое обеспечение в первое время после выхода на рынок труда, которого недостаточно для отделения от родителей, либо привычное удобство жизни в родительской семье.

Среди тех, кто не вступил в брак, также обнаруживаются равные доли по полу, медианный возраст аналогично предыдущей группе составляет 22 года, остальные характеристики в среднем слабо отличаются от общих значений по выборке. Это дает возможность предположить, что среди тех, кто пока не вступил в брак, нет каких-то особых случаев, просто молодежь не рассматривает это событие как одну из первоочередных целей и откладывает брак на более поздний возраст.

Таблица 4. Наступление в жизни молодежи от 18 до 29 лет такого события как... (\%)

\begin{tabular}{|c|c|c|c|c|c|c|c|c|c|}
\hline & $\begin{array}{c}\text { Окончили } \\
\text { школу/ } \\
\text { колледж/ } \\
\text { университет }\end{array}$ & $\begin{array}{c}\text { Отчислились } \\
\text { из школы/ } \\
\text { колледжа/ } \\
\text { университета }\end{array}$ & $\begin{array}{c}\text { Начали свою } \\
\text { первую } \\
\text { временную } \\
\text { работу (непол- } \\
\text { ная ставка) }\end{array}$ & $\begin{array}{c}\text { Начали свою } \\
\text { первую рабо- } \\
\text { ту на полную } \\
\text { ставку }\end{array}$ & $\begin{array}{c}\text { Съехали } \\
\text { от родите- } \\
\text { лей }\end{array}$ & $\begin{array}{c}\text { Начали } \\
\text { снимать квар- } \\
\text { тиру / платить } \\
\text { по ипотеке }\end{array}$ & $\begin{array}{c}\text { Начали жить } \\
\text { с партнером/ } \\
\text { партнершей }\end{array}$ & $\begin{array}{c}\text { Женились/ } \\
\text { вышли замуж }\end{array}$ & $\begin{array}{c}\text { У Вас родился } \\
\text { первый } \\
\text { ребенок }\end{array}$ \\
\hline $\begin{array}{l}\mathrm{He} \\
\text { происходило }\end{array}$ & 1,7 & 96,3 & 26,6 & 27,2 & 43,5 & 62,2 & 47,4 & 67,6 & 71,5 \\
\hline Происходило & 97,8 & 3,5 & 72,1 & 72,3 & 55,7 & 37,1 & 51,8 & 32,2 & 28,1 \\
\hline Нет ответа & 0,5 & 0,2 & 1,2 & 0,5 & 0,8 & 0,7 & 0,9 & 0,2 & 0,4 \\
\hline
\end{tabular}

Источник: Российское «Поколение Z»: Установки и ценности.

Данные свидетельствуют (см. табл. 4) о том, что большинство российской молодежи к 29 годам достигает только части объективизированных маркеров взросле- 
ния, проживая лишь часть социо-демографических событий. Подавляющее большинство молодежи оканчивает школу, получает профессиональное образование и выходит на рынок труда в позиции специалиста среднего уровня или рабочего. Около половины опрошенных молодых переезжают от родителей и начинают жить с партнером/партнершей. Вместе с тем такие этапы перехода во взрослость, как вступление в брак и рождение детей, большинство не успевает пройти в возрасте до 29 лет.

\section{Взросление как ответственность}

Ответственность за других - один из ключевых субъективизированных маркеров взрослости. Данные показывают, что взросление сопровождается повышением чувства ответственности у молодежи (см. табл. 5). Например, 75,4\% молодежи средней возрастной когорты и 79,8\% старшей в полной мере чувствуют ответственность за происходящее в своей семье, тогда как среди младшей возрастной когорты доля тех, кто в полной мере чувствует ответственность, составляет $50 \%$.

Таблица 5. В какой мере Вы чувствуете ответственность за то, что происходит в Вашей семье?, \%

\begin{tabular}{|l|c|c|c|c|c|}
\hline & $\begin{array}{c}\text { Младшая } \\
\mathbf{( 1 8 - 2 3 )}\end{array}$ & $\begin{array}{c}\text { Средняя } \\
\mathbf{( 2 8 - 3 3 )}\end{array}$ & $\begin{array}{c}\text { Старшая } \\
\mathbf{( 3 8 - 4 2 )}\end{array}$ & $\begin{array}{c}\text { Контрольная } \\
\mathbf{( 4 3 - 6 0 )}\end{array}$ & $\begin{array}{c}\text { Все } \\
\text { население }\end{array}$ \\
\hline 1. В полной мере & 50 & 75,4 & 79,8 & 74,9 & 71,8 \\
\hline 2. В значительной мере & 35 & 18,3 & 15 & 18,6 & 19,6 \\
\hline 3. В незначительной мере & 12,4 & 3,7 & 2,7 & 3,6 & 5,2 \\
\hline 4. Совершенно не чувствую & 2,2 & 2,3 & 2 & 2 & 2,5 \\
\hline 5. Затрудняюсь ответить & 0,4 & 0,3 & 0,5 & 0,9 & 0,8 \\
\hline Сумма & 100 & 100 & 100 & 100 & 100 \\
\hline Объем выборки, чел. & $\mathbf{2 2 6}$ & $\mathbf{3 5 0}$ & $\mathbf{4 0 6}$ & $\mathbf{1 0 0 9}$ & $\mathbf{3 2 0 9}$ \\
\hline
\end{tabular}

Источник: Курьер 2018-11, Курьер 2019-09.

В то же время общий уровень ответственности за происходящее на работе ниже, чем за то, что происходит в семье (см. табл. 6). Тем не менее здесь также обнаруживается динамика повышения ответственности у средней и старшей групп по сравнению с младшей.

Таблица 6. В какой мере Вы чувствуете ответственность за то, что происходит у Вас на работе?, \%

\begin{tabular}{|l|c|c|c|c|c|}
\hline & $\begin{array}{c}\text { Младшая } \\
(\mathbf{1 8 - 2 3 )}\end{array}$ & $\begin{array}{c}\text { Средняя } \\
\mathbf{( 2 8 - 3 3 )}\end{array}$ & $\begin{array}{c}\text { Старшая } \\
\mathbf{( 3 8 - 4 2 )}\end{array}$ & $\begin{array}{c}\text { Контрольная } \\
\mathbf{( 4 3 - 6 0 )}\end{array}$ & $\begin{array}{c}\text { Все } \\
\text { население }\end{array}$ \\
\hline 1. В полной мере & 18,1 & 34,3 & 32,8 & 28,5 & 25,2 \\
\hline 2. В значительной мере & 29,2 & 31,1 & 31,8 & 25,2 & 23,7 \\
\hline 3. В незначительной мере & 19,5 & 18 & 20 & 18,7 & 16,5 \\
\hline $\begin{array}{l}\text { 4. Совершенно } \\
\text { не чувствую }\end{array}$ & 10,2 & 10,6 & 10,8 & 10,8 & 14,1 \\
\hline 5. Затрудняюсь ответить & 23 & 6 & 4,7 & 16,7 & 20,6 \\
\hline Сумма & 100 & 100 & 100 & 100 & 100 \\
\hline Объем выборки, чел. & $\mathbf{2 2 6}$ & $\mathbf{3 5 0}$ & $\mathbf{4 0 6}$ & $\mathbf{1 0 0 9}$ & $\mathbf{3 2 0 9}$ \\
\hline
\end{tabular}

Источник: Курьер 2018-11, Курьер 2019-09. 
Наиболее частым ответом на вопрос о том, в какой мере респонденты чувствуют ответственность за происходящее в доме, во дворе, где они живут, стал “в незначительной мере" - его дали около трети респондентов каждой из выделенных групп молодежи (см. табл. 7). Однако и по данному показателю можно обнаружить тенденцию к большему чувству ответственности у людей более старшего возраста. Здесь наибольшие различия наблюдаются между представителями младшей и контрольной возрастной когортами. Причем в последней доля тех, кто в полной мере ощущает ответственность за то, что происходит в месте, в котором они живут, превышает долю ответивших таким же образом в младшей группе в два раза (31,8\% против 16,8\% соответственно).

Таблица 7. В какой мере Вы чувствуете ответственность за то, что происходит в доме, во дворе, где Вы живете?, \%

\begin{tabular}{|l|c|c|c|c|c|}
\hline & $\begin{array}{c}\text { Младшая } \\
\mathbf{( 1 8 - 2 3 )}\end{array}$ & $\begin{array}{c}\text { Средняя } \\
\mathbf{( 2 8 - 3 3 )}\end{array}$ & $\begin{array}{c}\text { Старшая } \\
\mathbf{( 3 8 - 4 2 )}\end{array}$ & $\begin{array}{c}\text { Контрольная } \\
\mathbf{( 4 3 - 6 0 )}\end{array}$ & $\begin{array}{c}\text { Все } \\
\text { население }\end{array}$ \\
\hline 1. В полной мере & 16,8 & 27,1 & 27,3 & 31,8 & 28,1 \\
\hline 2. В значительной мере & 25,7 & 28 & 29,3 & 24 & 25,6 \\
\hline $\begin{array}{l}\text { 3. В незначительной } \\
\text { мере }\end{array}$ & 34,1 & 31,1 & 32,5 & 29,6 & 30,1 \\
\hline $\begin{array}{l}\text { 4. Совершенно } \\
\text { не чувствую }\end{array}$ & 20,4 & 13,1 & 9,9 & 12,9 & 14,4 \\
\hline 5. Затрудняюсь ответить & 3,1 & 0,6 & 1 & 1,7 & 1,7 \\
\hline Сумма & 100 & 100 & 100 & 100 & 100 \\
\hline Объем выборки, чел. & $\mathbf{2 2 6}$ & $\mathbf{3 5 0}$ & $\mathbf{4 0 6}$ & $\mathbf{1 0 0 9}$ & $\mathbf{3 2 0 9}$ \\
\hline
\end{tabular}

Источник: Курьер 2018-11, Курьер 2019-09.

В меньшей степени россияне и российская молодежь чувствуют ответственность за происходящее в городе, районе, а еще меньший уровень чувства ответственности наблюдается у опрошенных за происходящее в стране (см. табл. 8 и табл. 9). Причем в данных показателях различия между возрастными когортами сглаживаются.

Таблица 8. В какой мере Вы чувствуете ответственность за то, что происходит в Вашем городе/районе?, \%

\begin{tabular}{|l|c|c|c|c|c|}
\hline & $\begin{array}{c}\text { Младшая } \\
(\mathbf{1 8 - 2 3 )}\end{array}$ & $\begin{array}{c}\text { Средняя } \\
\mathbf{( 2 8 - 3 3 )}\end{array}$ & $\begin{array}{c}\text { Старшая } \\
\mathbf{( 3 8 - 4 2 )}\end{array}$ & $\begin{array}{c}\text { Контрольная } \\
\mathbf{( 4 3 - 6 0 )}\end{array}$ & $\begin{array}{c}\text { Все } \\
\text { население }\end{array}$ \\
\hline 1. В полной мере & 9,3 & 14,3 & 14,3 & 16,1 & 14,6 \\
\hline 2. В значительной мере & 16,8 & 20,3 & 18 & 15,4 & 17,7 \\
\hline $\begin{array}{l}\text { 3. В незначительной } \\
\text { мере }\end{array}$ & 44,2 & 40,6 & 41,9 & 38,6 & 37,4 \\
\hline $\begin{array}{l}\text { 4. Совершенно } \\
\text { не чувствую }\end{array}$ & 27,9 & 23,7 & 23,4 & 28 & 28 \\
\hline 5. Затрудняюсь ответить & 1,8 & 1,1 & 2,5 & 2 & 2,3 \\
\hline Сумма & 100 & 100 & 100 & 100 & 100 \\
\hline Объем выборки, чел. & $\mathbf{2 2 6}$ & $\mathbf{3 5 0}$ & $\mathbf{4 0 6}$ & $\mathbf{1 0 0 9}$ & $\mathbf{3 2 0 9}$ \\
\hline
\end{tabular}

Источник: Курьер 2018-11, Курьер 2019-09. 
Таблица 9. В какой мере Вы чувствуете ответственность за то, что происходит в стране?, \%

\begin{tabular}{|l|c|c|c|c|c|}
\hline & $\begin{array}{c}\text { Младшая } \\
(\mathbf{1 8 - 2 3 )}\end{array}$ & $\begin{array}{c}\text { Средняя } \\
\mathbf{( 2 8 - 3 3 )}\end{array}$ & $\begin{array}{c}\text { Старшая } \\
\mathbf{( 3 8 - 4 2 )}\end{array}$ & $\begin{array}{c}\text { Контрольная } \\
\mathbf{( 4 3 - 6 0 )}\end{array}$ & $\begin{array}{c}\text { Все } \\
\text { население }\end{array}$ \\
\hline 1. В полной мере & 9,7 & 14 & 12,3 & 14,1 & 13,4 \\
\hline 2. В значительной мере & 15,9 & 14,3 & 15,5 & 13,2 & 15,3 \\
\hline $\begin{array}{l}\text { 3. В незначительной } \\
\text { мере }\end{array}$ & 33,6 & 31,4 & 33,3 & 28,9 & 28,5 \\
\hline $\begin{array}{l}\text { 4. Совершенно } \\
\text { не чувствую }\end{array}$ & 38,1 & 38,3 & 35,7 & 39,6 & 39,3 \\
\hline 5. Затрудняюсь ответить & 2,7 & 2 & 3,2 & 4,2 & 3,5 \\
\hline Сумма & 100 & 100 & 100 & 100 & 100 \\
\hline Объем выборки, чел. & $\mathbf{2 2 6}$ & $\mathbf{3 5 0}$ & $\mathbf{4 0 6}$ & $\mathbf{1 0 0 9}$ & $\mathbf{3 2 0 9}$ \\
\hline
\end{tabular}

Источник: Курьер 2018-11, Курьер 2019-09.

Рост ответственности молодежи за происходящее в семье и на работе, безусловно, связан с соответствующими транзициями. Меньше всего чувствуют ответственность 20-летние, которые в большинстве своем живут в родительской семье, делегируя ответственность за ее функционирование старшим, не получая, возможно, полного допуска к принятию решений. Кроме того, представители этой возрастной когорты еще не вышли полноценно на рынок труда, часть из них не имеет работы вовсе, а часть занимает стартовые позиции, не предполагающие высокий уровень личной ответственности. Однако с возрастом, накапливая жизненный, в том числе семейный и трудовой опыт, молодежь все больше чувствует ответственность. 30- и 40-летние россияне испытывают чувство ответственности за эти сферы в той же мере, что и "взрослая" контрольная когорта. Укорененность и распространение личной ответственности и на дом, и на двор растет на протяжении всей жизни. Меньше всего чувствуют ответственность за эти пространства самые молодые, а больше всего - люди в возрасте 43-60 лет. При этом и молодые, и взрослые россияне дистанцируются от того, что лежит за пределами их индивидуальной жизни, и не испытывают особой ответственности за происходящее в городе или стране. Таким образом, можно сказать, что взросление российской молодежи сопровождается увеличением личной ответственности за других в основном только в подконтрольных им жизненных пространствах.

\section{Взрослость как неопределенность, стабильность и уныние?}

Взрослость - это не только прохождение социо-демографических событий и рост ответственности, она также предполагает полноценный социальный и гражданский статус и автономию, возможность распоряжаться своей жизнью. Более того, взрослость, пишет Г. Блаттерер, “обещает" большее понимание себя и большую уверенность в себе, которые приходят с накоплением социальных компетенций [Blatterer, 2007: 776]. Например, планирование будущего связано с пониманием своих ресурсов и возможностью действовать [Leccardi, 2012] Если мы посмотрим на данные опросов, то увидим, что наибольшая доля молодых россиян планируют свое будущее на год-два вперед - такой ответ дают порядка $42 \%$ респондентов в каждой возрастной когорте среди миллениалов (см. табл. 10). При этом младшая и средняя когорты статистически значимо чаще, чем представители 
старшей, отмечают, что могут планировать свое будущее на ближайшие пять-шесть лет. В то время как у контрольной "взрослой" группы "поколения X" наблюдается иной модальный ответ — они не знают, что с ними будет даже в ближайшие месяцы.

Таблица 10. На сколько лет вперед Вы можете планировать свое будущее?, \%

\begin{tabular}{|l|c|c|c|c|c|}
\hline & $\begin{array}{c}\text { Младшая } \\
(\mathbf{1 8 - 2 3 )}\end{array}$ & $\begin{array}{c}\text { Средняя } \\
\mathbf{( 2 8 - 3 3 )}\end{array}$ & $\begin{array}{c}\text { Старшая } \\
\mathbf{( 3 8 - 4 2 )}\end{array}$ & $\begin{array}{c}\text { Контрольная } \\
\mathbf{( 4 3 - 6 0 )}\end{array}$ & $\begin{array}{c}\text { Все } \\
\text { население }\end{array}$ \\
\hline 1. На много лет вперед & 6,6 & 3,8 & 6,2 & 3,2 & 4,2 \\
\hline $\begin{array}{l}\text { 2. На ближайшие пять-шесть } \\
\text { лет }\end{array}$ & 20,8 & 18,5 & 12,1 & 10,3 & 13,7 \\
\hline 3. На ближайшие год-два & 42,5 & 42,5 & 42,8 & 38,3 & 37 \\
\hline $\begin{array}{l}\text { 4. Не знаю, что со мной } \\
\text { будет даже в ближайшие } \\
\text { месяцы }\end{array}$ & 26,5 & 30,6 & 35,8 & 44,6 & 41,1 \\
\hline 5. Затрудняюсь ответить & 3,5 & 4,6 & 3,1 & 3,7 & 4,1 \\
\hline Сумма & 100 & 100 & 100 & 100 & 100 \\
\hline Объем выборки, чел. & $\mathbf{2 2 6}$ & $\mathbf{3 7 2}$ & $\mathbf{3 5 5}$ & $\mathbf{1 0 1 4}$ & $\mathbf{3 2 0 9}$ \\
\hline
\end{tabular}

Источник: Курьер 2017-13, Курьер 2018-11.

При этом наибольшая доля и молодежи, и взрослых на вопрос об ожиданиях изменений в жизни через год отвечают, что будут жить так же, как и сейчас (см. табл. 11). Вариация доли ответивших таким образом в выделенных когортах слабая и колеблется между $46 \%$ и 49\%. Однако в младшей возрастной когорте сумма оптимистичных ответов - «Значительно лучше" и "Несколько лучше» - статистически значимо превышает сумму подобных ожиданий в других когортах.

Таблица 11. Через год Вы (Ваша семья) будете жить лучше или хуже, чем сейчас?, \%

\begin{tabular}{|l|c|c|c|c|c|}
\hline & $\begin{array}{c}\text { Младшая } \\
(\mathbf{1 8 - 2 3 )}\end{array}$ & $\begin{array}{c}\text { Средняя } \\
\mathbf{( 2 8 - 3 3 )}\end{array}$ & $\begin{array}{c}\text { Старшая } \\
\mathbf{( 3 8 - 4 2 )}\end{array}$ & $\begin{array}{c}\text { Контрольная } \\
\mathbf{( 4 3 - 6 0 )}\end{array}$ & $\begin{array}{c}\text { Все } \\
\text { население }\end{array}$ \\
\hline 1. Значительно лучше & 8,7 & 4,8 & 4,0 & 2,7 & 3,8 \\
\hline 2. Несколько лучше & 19,9 & 15,5 & 15,3 & 12,1 & 14,7 \\
\hline 3. Так же, как и сейчас & 46,7 & 47,1 & 46,2 & 48,8 & 48,3 \\
\hline 4. Несколько хуже & 16,5 & 22,1 & 22,9 & 22,7 & 21,3 \\
\hline 5. Значительно хуже & 2,9 & 6,6 & 7,1 & 8,3 & 7,0 \\
\hline 6. Затрудняюсь ответить & 5,3 & 4,0 & 4,5 & 5,3 & 4,9 \\
\hline Сумма & 100 & 100 & 100 & 100 & 100 \\
\hline Объем выборки, чел. & $\mathbf{5 5 2}$ & $\mathbf{8 3 3}$ & $\mathbf{1 0 1 5}$ & $\mathbf{2 5 7 0}$ & $\mathbf{8 7 8 3}$ \\
\hline
\end{tabular}

Источник: Курьер 2018-02, Курьер 2018-05, Курьер 2018-07, Курьер 2018-11, Курьер 2018 -13.

Важно подчеркнуть, что настрой на улучшение жизни молодой когорты и отсутствие ожиданий каких-либо изменений в старших группах - это не характеристики конкретных возрастных когорт, а эффект возраста. Десять лет назад те же возрастные группы показывали схожее распределение ответов по данному показателю (см. табл. 11). То есть люди, относящиеся к младшей возрастной группе 
на тот момент, сегодня попадают в среднюю группу, а средняя группа в 2010 г.в старшую в настоящее время. И мы видим, что их установки сместились в сторону пессимизма.

Таблица 11. Через год Вы (Ваша семья) будете жить лучше или хуже, чем сейчас? (2010 год), \%

\begin{tabular}{|l|c|c|c|}
\hline & $\begin{array}{c}\text { Младшая } \\
\mathbf{1 8 - 2 3}\end{array}$ & $\begin{array}{c}\text { Средняя } \\
\mathbf{2 8 - 3 3}\end{array}$ & $\begin{array}{c}\text { Все } \\
\text { население }\end{array}$ \\
\hline 1. Значительно лучше & 12,6 & 4,5 & 4,8 \\
\hline 2. Несколько лучше & 28,9 & 24,5 & 18,8 \\
\hline 3. Так же, как и сейчас & 39,6 & 43,2 & 47,6 \\
\hline 4. Несколько хуже & 3,1 & 5,8 & 8,5 \\
\hline 5. Значительно хуже & 1,3 & 0,6 & 2,2 \\
\hline 6. Затрудняюсь ответить & 14,5 & 21,3 & 18,2 \\
\hline Сумма & 100 & 100 & 100 \\
\hline Объем выборки, чел. & $\mathbf{1 5 9}$ & $\mathbf{1 5 5}$ & $\mathbf{1 6 1 9}$ \\
\hline
\end{tabular}

Источник: Курьер 2010-12.

Данные опроса показывают, что не только долгосрочность планов, настрой на позитивные изменения, но и удовлетворенность жизнью снижается по мере взросления (см. рис. 7). При этом схожая тенденция отмечалась и в 2011 г. [Гудков и др., 2011]. Иначе говоря, это вопрос не того, что какая-то из когорт просто более удовлетворена жизнью, чем другие, а того, что чем старше становятся россияне, тем меньше они удовлетворены своей жизнью.

Рис. 7. Если говорить в целом, в какой мере Вас устраивает сейчас жизнь, которую Вы ведете? ${ }^{5}, \%$

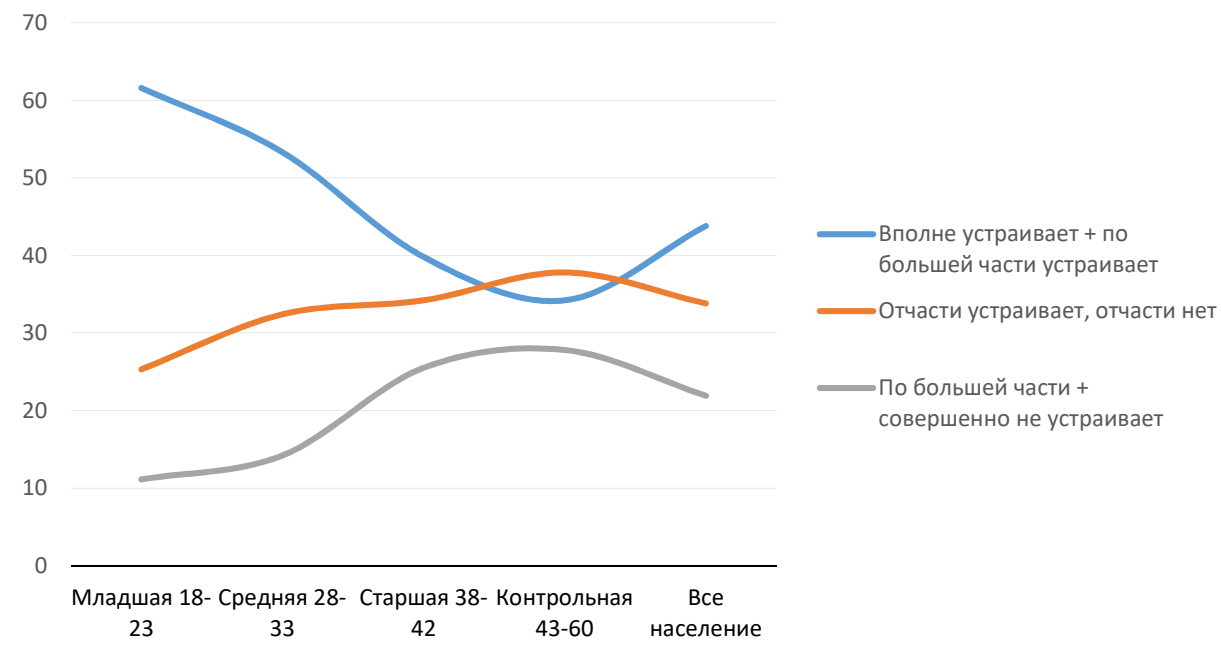

\footnotetext{
5 Источник: Курьер 2018-13.
} 
Кроме этого, среди молодежи младшей из рассматриваемых когорт обнаруживается наибольшая доля тех, кто отмечает свое настроение как прекрасное (см. табл. 12). Их доля статистически значимо превышает соответствующие доли в средней, старшей и контрольной когортах. Большинство же говорят, что находятся в нормальном, ровном состоянии - такой ответ дают $61 \%-64 \%$ опрошенных. Доля тех, кто испытывает напряжение или раздражение, растет от младшей к старшей и контрольной возрастным когортам.

Таблица 12. Что Вы могли бы сказать о своем настроении в последние дни? (\%, сумма по столбцу)

\begin{tabular}{|l|c|c|c|c|c|}
\hline & $\begin{array}{c}\text { Младшая } \\
(\mathbf{1 8 - 2 3 )}\end{array}$ & $\begin{array}{c}\text { Средняя } \\
\mathbf{( 2 8 - 3 3 )}\end{array}$ & $\begin{array}{c}\text { Старшая } \\
\mathbf{( 3 8 - 4 2 )}\end{array}$ & $\begin{array}{c}\text { Контрольная } \\
\mathbf{( 4 3 - 6 0 )}\end{array}$ & $\begin{array}{c}\text { Все } \\
\text { население }\end{array}$ \\
\hline 1. Прекрасное настроение & 23,0 & 15,6 & 14,0 & 8,4 & 11,9 \\
\hline $\begin{array}{l}\text { 2. Нормальное, ровное } \\
\text { состояние }\end{array}$ & 61,4 & 62,9 & 61,0 & 64,0 & 62,9 \\
\hline $\begin{array}{l}\text { 3. Испытываю напряжение, } \\
\text { раздражение }\end{array}$ & 12,3 & 18,6 & 21,6 & 21,5 & 19,7 \\
\hline 4. Испытываю страх, тоску & 3,3 & 2,3 & 2,9 & 5,3 & 4,7 \\
\hline 5. Затрудняюсь ответить & 0,0 & 0,6 & 0,6 & 0,7 & 0,8 \\
\hline Сумма & 100 & 100 & 100 & 100 & 100 \\
\hline Объем выборки, чел. & $\mathbf{5 5 2}$ & $\mathbf{8 3 3}$ & $\mathbf{1 0 1 5}$ & $\mathbf{2 5 7 0}$ & $\mathbf{8 7 8 3}$ \\
\hline
\end{tabular}

Источник: Курьер 2018-02, Курьер 2018-05, Курьер 2018-07, Курьер 2018-11, Курьер 2018-13.

Взросление в современной России связано с сужением горизонтов планирования, снижением ожидания позитивных изменений в жизни, ростом неудовлетворенности и плохого настроения. Важно подчеркнуть, что данные тенденции связаны именно с возрастным эффектом, а не с поколенческими различиями.

\section{Заключение}

Переход во взрослость российского поколения миллениалов в первую очередь сопряжен с получением образования и выходом на рынок труда. До 30 лет эти события переживает большинство молодежи. При этом затраченное на образование время и его уровень у молодого поколения выше, чем у старших возрастных когорт. Это вполне соответствует мировым тенденциям. Дж. Бессант с коллегами указывают на то, что становление неолиберального капитализма с идеями личной ответственности за свою жизнь принуждает молодежь к инвестированию в образование, суля не вполне реализуемые обещания лучшей жизни [Bessant, Farthing, Watts, 2017]. Звучащие иногда обвинения молодежи в инфантильности и нежелании работать не находят подтверждения в опыте ни российской, ни европейской молодежи, которая наделяет работу высокой ценностью и стремится к ней [O'Reilly et al., 2018].

Переезд от родителей и начало совместного проживания с партнером/партнершей молодые совершают после получения образования и начала работы на полную ставку. Однако эти транзиции переживает только примерно половина россиян до 29 лет. В то же время такие демографические события, как брак и рождение первого ребенка, до 29 лет происходят только у трети молодежи. К сожалению, используемые нами для анализа данные не позволяют отследить наступление 
этих событий в более поздних возрастах. Но общая тенденция откладывания вступления в брак и рождения детей характерна в целом для второго демографического поворота в современном обществе [Демографическая модернизация России, 2006]. Исследователи советских и российских поколений показывают, что чем моложе поколение, тем позже происходит отделение от родителей, а также демографические события [Митрофанова, 2019; Долгова, Митрофанова, 2015]. Полагаем что и мы наблюдаем в поколении миллениалов продолжение, а, возможно, и усиление данной тенденции.

Анализ объективизированных маркеров взрослости показывает, что взросление российской молодежи растягивается во времени. Ее взросление начинается с получения образования и работы, в то время как брак и деторождение откладываются во времени, за пределы "молодого" возраста, выступая, вероятно, уже реализацией взрослого этапа жизни, нежели подготовкой к нему. При этом взросление для российских миллениалов, так же как и для молодежи в других европейских и северо-американских странах [Pitti, 2017; Arnett, 2014], сопровождается ростом чувства ответственности за других. И эта ответственность индивидуализированная, непосредственно связанная с теми сферами жизни, на которые молодежь может влиять,- - семья, работа, дом.

Однако, как показывают используемые здесь данные, достижение взрослости сопровождается для россиян потерей жизненного оптимизма. С увеличением возраста сокращаются горизонты планирования, люди в меньшей степени ориентируются на ожидание позитивных перемен. Более того, они реже пребывают в хорошем настроении и чаще, чем в молодости, испытывают негативные эмоции.

Можно сказать, что молодые россияне взрослеют не так, как их родители и бабушки с дедушками, но так, как взрослеют их ровесники во многих других странах в современном мире. Они долго учатся, активно начинают работать, откладывают брак и рождение детей на более поздний срок, становясь с возрастом более ответственными. Однако то, как они чувствуют себя по мере взросления, делает актуальным большой вопрос: а стоит ли наделять взрослость значением важности завершения пути, стоит ли к ней стремиться? Если опираться на субъективные ощущения удовлетворенностью жизнью и настроения 40-летних, то взрослость выглядит скорее как стагнация и уныние, чем обретение уверенности в себе, автономии, потенциала реализации. Очевидно, что у используемых в статье данных количественных замеров и опросов недостаточно интерпретационных ресурсов. Вероятно, дополнение предложенных здесь результирующих суждений качественными данными разговора с представителями выделенных групп помогли бы четче и ярче прописать обозначенное противоречие: молодость как некая промежуточная позиция "невзрослости" и взрослость как желаемый "пункт назначения" оборачиваются незавершенной транзицией. Если придерживаться такого подхода, то взрослость выглядит унылым и застывшим местом, реализация потенциала которого ставится под вопрос. Может быть, пришло время перенести фокус внимания исследователей с молодости на взрослость. Представляется, что проведение таких исследований как в качественной, так и количественной методологиях помогло бы рассмотреть разнообразие взрослостей и их смыслов для проживающих этот период жизни современников. 


\section{Список литературы (References)}

Ардельянова Я.А., Саидов Б.Ш. Факторы и условия инфантилизации современной молодежи // Теория и практика общественного развития. 2018. № 4. https:/ /doi. org/10.24158/tipor.2018.4.6.

Ardelyanova Y., Saidov B. (2018) Factors and Conditions of the Infantilization of the Modern Youth. Theory and Practice of Social Development. No. 4. https://doi. org/10.24158/tipor.2018.4.6. (In Russ.)

Гудков Л.Д., Дубин Б. В., Зоркая Н. А. Молодежь России. М. : Московская школа политических исследований, 2011.

Gudkov L., Dubin B., Zorkaya N. (2011) Youth of Russia. Moscow: Moscow School of Political Studies. (In Russ.)

Демографическая модернизация России, 1900-2000 / под ред. Вишневского А.Г. М. : Новое издательство, 2006. 608 с.

Vishnevsky A. (ed.) (2006) Demographic Modernization of Russia, 1900-2000. Moscow: New Publishing House. (In Russ.)

Долгова А. А., Митрофанова Е. С. Отделение от родительской семьи в России: межпоколенческий аспект // Экономическая социология. 2015. Т. 16. № 5. С. 46-70. Dolgova A., Mitrofanova E. (2015) Leaving the Parental Home in Russia: Intergenerational Aspects. Journal of Economic Sociology. Vol. 16. No. 5. P. 46-76. (In Russ.)

Зубок Ю.А., Чупров В.И. Жизненные стратегии молодежи: реализация ожиданий и социальные настроения // Мониторинг общественного мнения: экономические и социальные перемены. 2020. № 3. С. 13-41. https://doi.org/10.14515/ monitoring.2020.3.1602.

Zubok J. A., Chuprov V. I. (2020) Youth Life Strategies: Implementation of Expectations and Social Moods. Monitoring of Public Opinion: Economic and Social Changes. No. 3. P. 13-41. https://doi.org/10.14515/monitoring.2020.3.1602. (In Russ.)

Мамычева Д. И. Трансформации категорий "Детство" и “Взрослость" в современной культуре / / Общество. Среда. Развитие (Terra Humana). 2010. № 3. С. 75-80 Mamycheva D. (2010) Transformations of the Categories "Childhood" and "Adulthood" in Modern Culture. Society. Environment. Development (Terra Humana). No. 3. P. 7580. (In Russ.)

Митрофанова, Е. С. Модели взросления разных поколений россиян // Демографическое обозрение. 2019. Т. 6. № 4. С. 53-82.

Mitrofanova E. (2019) Models of the Transition to Adulthood of Different Russian Generations. Demographic Review. Vol. 6. No. 4. P. 53-82. (In Russ.)

Омельченко Е. Л. Вместо введения. 25 лет молодежных исследований: глобальные имена - локальные тренды // Молодежь в городе: культуры, сцены и солидарности / под. ред. Омельченко Е. Л. М. : Изд. дом Высшей школы экономики. С. 29-91. Omelchenko E. (2020) Instead of an Introduction. 25 Years of Youth Research: Global Names - Local Trends. In: Omelchenko E. (ed.) Youth in the City: Cultures, Scenes and Solidarities. Moscow: HSE Publishing House. P. 29-91. (In Russ.) 
Павленко Е. С. Взросление как процесс формирования идентичности: возможности анализа нарративов // Вестник Российского университета дружбы народов. Серия: Социология. 2016. Т. 16. № 2. С. 258-269.

Pavlenko E. (2016) Life Trajectory as a Process of Identity Formation: The Potential of Narrative Analysis. RUDN Journal of Sociology. Vol. 16. No. 2. P. 258-269. (In Russ.)

Павленко Е. С., Якубовская А. А. Интерпретации взросления и формирование образовательных траекторий // Мониторинг общественного мнения: экономические и социальные перемены. 2020. № 3. С. 376-390. https://doi.org/10.14515/ monitoring.2020.3.1604.

Pavlenko E., Yakubovskaya A. (2020) Interpretations of Adulthood and Formation of Educational Trajectories. Monitoring of Public Opinion: Economic and Social Changes. No. 3. P. 376-390. https://doi.org/10.14515/monitoring.2020.3.1604. (In Russ.)

Радаев В. В. Миллениалы: как меняется российское общество. М.: Изд. дом Высшей школы экономики, 2019.

Radaev V. (2019) Millennials: How Russian Society is Changing. Moscow: HSE Publishing House. (In Russ.)

Чернова Ж.В., Шпаковская Л.Л. Переход к взрослой жизни молодых людей, имеющих опыт институциональной заботы // Мониторинг общественного мнения: экономические и социальные перемены. 2020. № 3. C. 94-118. https://doi. org/10.14515/monitoring.2020.3.1618.

Chernova Z. V., Shpakovskaya L. L. (2020) Institution-Reared Children and Their Transition to Adulthood. Monitoring of Public Opinion: Economic and Social Changes. No. 3. P. 94-118. https://doi.org/10.14515/monitoring.2020.3.1618. (In Russ.)

Arnett J. J. (2014) Emerging Adulthood. The Winding Road from the Late Teens Through the Twenties. Oxford: Oxford University Press.

Beattie I. R. (2017) Tracking Women's Transitions to Adulthood: Race, Curricular Tracking, and Young Adult Outcomes. Youth and Society. Vol. 49. No. 1. P. 96-117. https://doi.org/10.1177/0044118X14527467.

Berzin S. C., Marco De A. C. (2010) Understanding the Impact of Poverty on Critical Events in Emerging Adulthood. Youth and Society. Vol. 42. No. 2. P. 278-300. https:// doi.org/10.1177/0044118X09351909.

Bessant J., Farthing R., Watts R. (2017) The precarious generation. A political economy of young people. London, New York: Routledge.

Blatterer H. (2010) The Changing Semantics of Youth and Adulthood. Cultural Sociology. Vol. 4. No.1. P. 63-79. https://doi.org/10.1177/1749975509356755.

Blatterer H. (2007) Contemporary Adulthood: Reconceptualising an Uncontested Category. Current Sociology. Vol. 55. No. 6. P. 771-792. https://doi.org/10.1177/ 0011392107081985.

Carpenter S., Mojab S. (eds.) (2017) Youth as/in Crisis. Young People, Public Policy, and the Politics of Learning. Rotterdam, Boston, Taipei: Sense Publishers. 
Hayward K. (2013) Life Stage Dissolution' in Anglo-American Advertising and Popular Culture: Kidults, Lil' Britneys and Middle Youths. The Sociological Review. Vol. 61. No. 3. P. 525-548. https://doi.org/10.1111/1467-954X.12032.

Krahn H. J., Chai C., Fang S., Galambos N. L., Johnson M. D. (2018) Quick, Uncertain, and Delayed Adults: Timing, Sequencing and Duration of Youth-Adult Transitions in Canada. Journal of Youth Studies. Vol. 21. No. 7. P. 905-921. https://doi.org/10.1 080/13676261.2017.1421750.

Kravchenko Z. (2015) Transition Into Adulthood and Inequalities: The Institutional Perspective. The Journal of Social Policy Studies. Vol. 13. No. 2. P. 303-316.

Leccardi C. (2012) Changing Time Experience, Changing Biographies and New Youth Values. In: Hahn-Bleibtreu M., Molgat M. Opladen (eds.) Youth Policy in a Changing World. From Theory to Practice. Berlin, Toronto: Barbara Budrich Publishers. P. 225-237.

Omelchenko E. L., Nartova N., Krupets Y. (2018) Escaping Youth: Construction of Age by Two Cohorts of Chronologically Young Russian Women. Young. Vol. 26. No. 1. P. 34-50. https://doi.org/10.1177/1103308816680305.

O’Reilly J., Leschke J., Ortlieb R., Seeleib-Kaiser M., Villa P. (eds.) (2018) Youth Labour in Transition: Inequalities, Mobility, and Policies in Europe. Oxford: Oxford University Press.

Patrick M.E., Schulenberg J. E., O’Malley P.M. (2016) High School Substance Use as a Predictor of College Attendance, Completion, and Dropout: A National Multicohort Longitudinal Study. Youth and Society. Vol. 48. No. 3. P. 425-447. https://doi. org/10.1177/0044118X13508961.

Pitti I. (2017) What Does Being an Adult Mean? Comparing Young People's and Adults' Representations of Adulthood. Journal of Youth Studies. Vol. 20. No. 9. P. 1225-1241. https://doi.org/10.1080/13676261.2017.1317336.

Smith C., Christoffersen K., Davidson H., Herzog P.S. (2011) Lost in Transition: The Dark Side of Emerging Adulthood. Oxford: Oxford University Press.

Irwin S., Nilsen A. (eds.) (2018) Transition to Adulthood Through Recession. Youth and Inequality in a European Comparative Perspective. London, New York: Routledge.

Twigg J. (2004) The Body, Gender, and Age: Feminist Insights in Social Gerontology. Journal of Aging Studies. Vol. 18. No. 1. P. 59-73. https://doi.org/10.1016/j.jaging.2003.09.001.

Vogt K. C. (2018) From Job-Seekers to Self-Searchers: Changing Contexts and Understandings of School-to-Work Transitions. Young. Vol. 26. No. 4_s. P. 18S-33S. https://doi.org/10.1177/1103308817741006.

Walsh L., Keary A., Gleeson J. (2019) Non-linear Transitions: An Intergenerational Longitudinal Study of Today's Young Women in Education and Work. Young. Vol. 27. No. 5. P. 468-485. https://doi.org/10.1177/1103308818817632.

Walther A. (2006) Regimes of Youth Transitions: Choice, Flexibility and Security in Young People's Experiences across Different European Contexts. Young. Vol. 14. No. 2. P. 119-139. https://doi.org/10.1177/1103308806062737. 